\title{
The Importance Of Imbedding The Concept Of Continuous Development In The Formulation Of Global Strategies
}

John Theodore, JDT Management Consultants, USA

\begin{abstract}
This article deals with the importance of incorporating the concept of continuous development in the formulation of strategy in global organizations where the strategists have to focus their attention on both the external and internal environmental forces of the firms. In the external environment, the social and task elements are to be analyzed and examined; the latter include the industry analysis. In the internal environment, analysis and evaluation must take place in the organizational structure, principles of organization, culture, and the human element. Continuous development is within the concept of organizational development, which is a planned change effort that involves all the parts of the organization. It is initiated and managed from the top hierarchy of the system and is designed to increase organizational effectiveness. Continuous development must concentrate on the development of the organizational structure, policies and procedures, performance appraisals, the management, the employees, communications, and on the leadership of the organization because these elements are fundamental in the corporate strategy. The continuous developmental process is concentrated within the internal environment of the organization.
\end{abstract}

Keywords: Global Organizations; Global Strategies; Learning Organizations; Organic Structures; Organizational Development; Development Interventions; Development; Leadership; Transformational Leadership; DecisionMaking, Formulation of Strategies; Global Strategy; Management; Business Strategic Level; Functional Strategic Level; Corporate Strategic Level; SWOT Analysis; Communication; Policies and Procedures; Complex Environment; Diversity; Organizational Structure; Management Development; Employee Development; Evaluation of the Human Element

\section{INTRODUCTION}

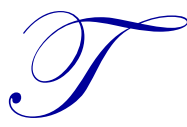

he purpose of this paper is to present the importance of incorporating the element of continuous development in the formulation of global strategies. The author of this work views management as the task of planning, organizing, staffing, directing, and controlling organizational activities in order to accomplish organizational goals. Another definition of management indicates that it is the process of working with people and resources to accomplish organizational goals (Bateman \& Snell, 2012).

Strategic management (from the Greek strategos - supreme commander of the armed forces) is a set of decisions and actions that result in the formulation and implementation of plans designed to achieve an organization's objectives (Pearce \& Robinson, 2007). Finally, global strategies encompass those that are prepared to be implemented on a global basis. A global strategy can be defined as a "strategy of firms around the globe whose theory is about how to compete successfully" (Peng, 2006, p. 18).

\section{GLOBAL STRATEGIC LEVELS}

Global organizational strategies have two important levels - other authors add a functional level whose elements, in this study, are included in the corporate level. The first is the business-level which encompasses the 
overall competitive theme that an organization chooses to stress and the way it positions itself in the marketplace to gain a competitive advantage and the different positioning strategies that can be used in different industry settings (Hill \& Jones, 2012).

The second is the corporate level strategy which indicates the desired results or targets that strategy managers have established. Each "functional area and each business unit should also have goals that are being pursued. The corporate objectives need to be broader, more comprehensive, and more long run than those in other levels" (Coulter, 2002, p. 280). The center of continuous development takes place in this level and the benefits are also being received by the business level.

\section{GLOBAL STRATEGIC FORMULATION}

In the global strategic formulation process, the strategists of the organization have to focus their attention on both the external and internal environment of the firm. In the external environment, the elements to be analyzed and examined are the society environment and its general forces and the task environment which includes the industry analysis, whereas in the internal environment, analysis and evaluation must take place on the organizational design, principles of organization, culture, and the human element (Hunger \& Wheelen, 2010).

In the formulation of global strategies, it is imperative to consider the region-Latin America, the European Union, or the Middle East - in which the organization operates because "since globalization has started, strategy at the regional level is more important than ever" (Ghemawat, 2007, p. 140).

The analysis and evaluation of the internal and external environment is better known as a SWOT Analysis which focuses on the strengths and weakness of the internal environment and on the opportunities and threats of the external one. The strategists responsible for continuous development carefully analyze the results of the SWOT Analysis and, based on such results, formulate a continuous developmental process which eliminates the weakness found and begins the development of human and non-human elements in the functional units and in the organizational structure and the principles of organization that are imbedded in such structure (Theodore, 2003).

The author of this work believes that continuous development must concentrate on the development of leadership of the organization, the management, employees, performance appraisal of the human element, the organizational structure, communications, and on policies and procedures because these elements are fundamental in the corporate strategy of the firm. The continuous developmental process is concentrated within the internal environment of the organization.

\section{THE IMPORTANACE OF CONTINUOUS DEVELOPMENT}

Continuous development is within the concept of organizational development which is a "planned change effort that involves all the parts of the organization. It is initiated and managed from the top hierarchy of the system and is designed to increase organizational effectiveness" (Schein, 1985, p. 16).

The ultimate goal of organizational development "is to make the organization more open and adaptive through increases in capability and potential in order for it to continue making such planned change efforts on an action-orientation basis" (French \& Bell, 1978, p. 21). This developmental process is based on Kurt Lewin's theory of unfreezing from the status quo, making the change, and refreezing in order to maintain the attained change (Lewin, 1947, pp. 5-11). This three-step process continues without interruption in order for the organization to be subjected to continuous organizational development.

\section{Continuous Leadership Development}

Strategic leadership is the "process of providing the direction and inspiration necessary to create and implement a vision, a mission, and strategies to achieve and sustain organizational objectives" (Lussier \& Alachua, 2007, p. 460). Leaders set the tone for the organizations and make choices and investments that determine how organizations work (Ulrich \& Ulrich, 2010). 
Effective leaders play a paramount role in the development of their organizations. Such leaders have managed to "evolve their organizations from relatively small national players to major worldwide competitors, challenging the dominance of traditional leaders in their businesses" (Bartlett, Ghoshal, \& Birkinshaw, 2004, p. 214). Furthermore, the emergence of a visionary leader can be a major catalyst in breaking down existing geographic and competitive boundaries (de Kluyver, 2010).

The leaders of global organizations - because of the complexity and diversity of both the internal and external environment - must be transformational leaders who create a metamorphosis among their followers in accepting the mission, goals, and objectives of the organization; in looking at the interest of the entire organization rather than their individual interests; and in precipitating organizational development through a continuous developmental process (Theodore, 2013). The global leader is willing to challenge the status quo while trusting and empowering people (Bantu-Gomez, 2011).

Continuous development interventions in this area aim at the needs of the leaders and the epicenter of the interventions is to analyze, evaluate, and develop important leadership elements, such as values, mental ability, perceptions, and interpersonal skills.

Continuous Management Development provides the dexterity that global leaders need in dealing with the human and non-human elements to perform their jobs effectively and efficiently in global internal and external environments characterized by complexity and diversity.

Management development is dedicated to enhancing leadership and expanding and improving more general management skills (Mehmood \& Arif, 2011). Managing a "broad geographic scope of operations with complex integration needs is a difficult management challenge" (Tallman, 2009, p. 37). Such managers have distinct divergent backgrounds that reflect the culture of his or her country.

Global managers must recognize opportunities and threats in their organization's external environment. They must be aware of what is going on outside their firm (Ketchen, Eisner, Dess, \& Lumpkin, 2009). Management development in global organizations pivots around the development of the middle and upper organizational echelon and prepares those managers to assume their respective responsibilities by having superior knowledge and skills in their respective functional areas (Anderson, 2010).

One of the aims of the developmental process is to make the organization a learning one where people continually expand their capacities to create the results they truly desire, environments where new and expansive patterns of thinking are nurtured, entities designed to set free collective aspirations, and where people are continually learning to see the whole together (Senge, 1990).

Global organizations can operate effectively and efficiently in the global environment only if they are learning organizations which have an organic infrastructure and essence conducive to continuous adaptability to the ever-changing complex and divergent external environment. Developmental learning needs to take place in both the functional areas of the managers and in increasing their educational standards in world affairs that affect the operation of their organization. This type of learning enhances the knowledge of the human factor to better understand the external environment of the organization and how such an organization is functioning within the micro and macro external environment on a global basis (Theodore, 2012). Behind appropriate policies, strategies, and structures are the effective learning processes whose creation is a key design responsibility in learning organizations (Segal-Horn, 2002).

The developmental interventions in this area are directed at the three important skills managers must have conceptual, human relations, and technical. The intervention pivots around the analysis and evaluation of the developmental necessities managers have; the analysis and evaluation of developmental training dealing with the elements of management; and the analysis and evaluation of the needs of the managers.

Continuous Employee Development is an ongoing process that includes the work performed by the nonmanagerial personnel in the organization. Such employees have distinct divergent backgrounds that reflect the 
culture of their countries and operate in environments that reflect complexity and diversity. The development each employee receives leads to creating stability and confidence that he or she can contribute to the development of the organization itself (Winden, Gudergan, \& Lings, 2010).

One of the most common approaches to personnel performance evaluation is the periodic appraisal of work performance and how they differ, although the objective is similar from country to country. Employee development is highly supported by the leaders of the organizations who build on their own strengths but also help their employees to do the same (Ulrich \& Ulrich, 2010).

In the area of employee development that entails change, one frequently detects that there is resistance against change by the employees because of many reasons, the most important of which is fear of the unknown. Change, whether in structure, process or procedure, always involves and impacts the human dimensions of organizations (Ketchen, Eisner, Dess \& Lumpin, 2009). However, if the strategists who are conducting the developmental process use good coaching and appropriate development programs, most employees will adapt to change and be participants in the developmental process of the organization (Porth, 2003).

Development and training, psychological support, and participation all increase the likelihood that employees will understand and feel comfortable with organizational changes (Bolman \& Deal, 2008). The success of the non-managerial personnel depends on the strategists responsible for the development process who, in this case, need to construct programs conducive to the development of the human factor. This is conducive to acquiring and developing global knowledge that depicts the human factor in organizations with superior capability to access, and mobilize and leverage untapped pockets of knowledge scattered around the world (Bartlett, Ghoshall, \& Birkinshaw, 2004). Laconically stated, this process develops the human capital of the organization. Human capital "consists of individual knowledge, skills, capabilities, qualifications, and training that contribute to a person's talent” (Hargreaves \& Shirley, 2012, p. 49)

The development interventions in this area pivot around the analysis, evaluation, and satisfaction of human needs, as well as those areas where the employees are performing in their respective functional units. Furthermore, the developmental interventions create job enrichment for the employees, which is conducive to a more meaningful and rewarding job by providing challenging tasks on a short- and long-term basis.

\section{Continuous Evaluation of the Human Element}

The human element includes both the executive, managerial, and non-managerial classifications of employees in global organizations that are surrounded by micro and macro environmental complexity and diversity. Performance appraisals refer to the systematic description and review of an individual's job performance in order to improve the overall performance of the organization (Bowin \& Harvey, 2001). Job satisfaction is an integral part of good organization performance and it is precipitated by incentives, quality of the work environment, the challenging nature of the work, and the satisfaction of the employee's needs (Nadim \& Khan, 2013).

The performance evaluators of the human element in a global environment must consider the complexity of such an environment and the diversity of the employees and managers. The strategic evaluators need to have established performance targets, standards, tolerance limits for the objectives, strategy, and implementation plans (Bohlander \& Snell, 2013). They measure the actual performance in relation to the targets given at a time, as well as analyzing deviations and executive modifications, if necessary (London \& Hart, 2011).

The development interventions in this area focus upon enhancing the ability of the human factor to perform assigned tasks. Evaluators; evaluation tools, methods, and procedures; and legal, social, and ethical elements are included in the evaluation process.

\section{Continuous Development of Organizational Structure}

Organizational structures denote the relationships among elements and the principles of organization. The recent interest in developing organizational structures is a result of new organizational challenges such as flexibility, resilience, customer focus, social responsibility, and environmental respect (Gulati, Puranam, \& Tushman, 2012). 
Global organizational structures are influenced by the firm's economic situation, the type of product, technology, managerial preferences, and the respective country's culture that includes economic, technological, and political conditions (Rodrigues, 2001). The organizational structure "incorporates departmentalization; delegation of authority and responsibility and its parity; unity of command; span of control; and, finally, the elements of horizontal and vertical communication" (Theodore, 2003, p. 5). When designing an organization, the organization's strategy and consistency with the demands of the environment play a very important role (Ketchen, Eisner, Dess, \& Lumpkin, 2009). Because global organizations are exposed to a variety of global complexities and diversities, their organizational structures must be organic, which means that they need to be highly adaptive, relatively flat, use teams to cut across functional departments and hierarchical levels, have low formalization, possess a comprehensive information network, and actively involve all employees in decision-making (Robbins, 2000).

In order to maintain an organic structure, continuous development must take place through well-planned and implemented interventions in order to develop positional roles and relationships that precipitate more effective arrangements in tasks, resources, and hierarchal responsibilities.

\section{Continuous Development of Communication}

Communication is the process of transmitting information from one source to another. The organizational structure defines formal methods of hierarchal communication, reporting, resource allocation, compensation, information access, and decision-making (Rajaeepoour, Arbabisarjou, Zivarirahman, \& Shokoumi, 2012). Global organizations operate within the confines of a large global environment and use both intra-unit and inter-unit communications - a unit is a branch of the organization or the central part of it. Organizational communication is vertical and horizontal (Krizan et al., 2008). Vertical communication moves up and down in the organizational structure (Jones \& George, 2007). And horizontal communication flows horizontally and includes individuals of the same rank, both within the same department and among departments. It assists the coordination of the various and divergent organizational elements and strengthens the decision-making process in both entities.

Because of the cultural complexity and diversity of the global environment, information deficiencies pertinent to ineffective gaps of knowledge about important elements frequently arise within and outside the organization (London \& Hart, 2011). This situation is a major concern for the strategists who need to develop effective communication and have functional and well-structured communication channels. Effective communication occurs when there is no distortion of the message (Rodrigues, 2001).

Development interventions in the intra-unit areas focus on developing the unit's members to better analyze and understand the demands of their respective functional units and to provide effective, efficient, and timely feedback through the channels of communication within the unit.

On the other hand, development interventions in inter-unit communication aim at the development of intergroup interactions in order to implement the goals of the organization correctly; to change the perception the employees have in one unit toward the employees of the other units; and improve feedback and the communication channels between/among units.

\section{Continuous Development of Policies}

Policies are rules, regulations, and guidelines that describe the areas in which employees and groups of employees perform their respective tasks. Policies in global organizations are replete with elements that address the operation of the organization in complex environments and diversity elements. Policies facilitate solving recurring problems and guide the strategy of the implementation. Policy refers to specific guidelines, methods, procedures, rules, forms, and administrative practices established to support and encourage work toward stated goals (David, 1995).

The implementation of organizational strategies is being conducted within the areas specified by policies. Policies and procedures are directly related to the mission, goals, and objectives of the organization. New or revised/developed policies and procedures provide top-down guidance to train the entire personnel regarding how 
certain things now need to be done and thus establishing regularity, stability, and dependability in how management has decided to try to execute the strategy and operate the organization (Thompson, Strickland, \& Gamble, 2009).

The formulation and development of policies takes under consideration the ever-changing demands of the internal and external environment in which the organization operates and must be flexible in order to react correctly to internal and external organizational changes. Human resources policies guide the human factor and non-human resources policies are pertinent to organizational elements, such as production or distribution (Noe, Hollenbeck, Gerhart, \& Wright, 2010).

The goal of the development interventions in this area aims at the analysis and evaluation of existing organizational policies and procedures in order to create and develop non-human resources policies conducive to better operation and control of the organization and also create and develop human resources policies conducive to a Theory Y organizational environment.

\section{CONCLUSIONS}

The purpose of this article was to present the importance of incorporating the element of continuous development in the formulation of global strategies.

Global organizational strategies have two important levels. The first is the business-level that encompasses the overall competitive theme that an organization chooses to stress and the way it positions itself in the marketplace to gain a competitive advantage, as well as the different positioning strategies that can be used in different industry settings. The second is the corporate level strategy which indicates the desired results or targets that strategy managers have established.

In the global strategic formulation process, the strategists have to focus their attention on both the external and internal environments of the firm. Continuous development is within the concept of organizational development which is a planned change effort that involves all parts of the organization. It is initiated and managed from the top hierarchy of the system and is designed to increase organizational effectiveness.

The author of this work believes that continuous development must concentrate on the development of the organizational structure, policies and procedures, performance appraisals, the management, the employees, communications, and on the leadership of the organization because these elements are fundamental in the corporate strategy of the organization. The continuous developmental process is concentrated within the internal environment of the organization.

\section{AUTHOR INFORMATION}

John Theodore is the holder of a Ph.D. degree in Administration and Latin American Studies from the University of Kansas; a Ph.D. in Management from the Aristotelian University in Greece, European Union; and a D.B.A. in International Business from the University of South Africa. He has been teaching and consulting for four decades domestically and internationally. He is a visiting professor in various foreign universities. Dr. Theodore is the president of JDT Management Consultants in Clearwater, Florida, specializing in management, organization, strategy, international business, human resources, organizational development, and educational administration. He is a certified management consultant (CMC) certified by the Institute of Management Consultants in Washington, D.C. E-mail: jdtheodore@tampabay.rr.com

\section{REFERENCES}

1. Anderson, D. L. (2010). Organization development: The process of leading organizational change. Thousand Oaks, CA: Sage Publications, Inc.

2. Bartlett, C. A., Ghoshal, S., \& Birkinshaw, J. (2004). Transnational management. Boston: McGraw-Hill Irwin. 
3. Bantu- Gomez, M. B. (2011). Global leadership, change, organizations, and development. Bloomington, IN: Universe.

4. Bateman, T. S., \& Snell, S. A. (2012): Management: Competing in the new era (10 ed.). Boston: McGrawHill Irwin.

5. Bohlander, G. W., \& Snell, S. (2013). Managing human resources $\left(16^{\text {th }}\right.$ ed.). Mason, OH: South-Western Cengage Learning.

6. Bolman, L. G., \& Deal, T. E. (2008). Reframing organizations: Artistry, choice, and leadership. San Francisco: John Wiley \& Sons.

7. Bowin, R. B., \& Harvey, D. F. (2001). Human resource management: An experiential approach. Upper Saddle River, NJ: Prentice Hall.

8. Coulter, M. (2002). Strategic management in action. Boston: Pearson Custom.

9. David, F. R. (1995). Strategic management (5th ed.). Englewood Cliffs, NJ: Prentice Hall.

10. de Kluyver, C. A. (2010). Fundamentals of global strategy: A business model approach. New York: Business Expert Press.

11. French, W. L., \& Bell, C. H. (1978). Organization development: Behavioral science interventions for organization improvement $\left(2^{\text {nd }}\right.$ ed.). Englewood Cliffs, NJ: Prentice Hall.

12. Ghemawat, P. (2007). Redefining global strategy. Boston: Harvard Business School Press.

13. Gulati, R., Puranam, P., \& Tushman, M. (2012). Meta-organization design: Rethinking design in interorganizational and community contexts. Strategic Management Journal, 33(6), 571-586. doi:10.1002/smj.1975

14. Hargreaves, A., \& Shirley, D. (2012). The global fourth way. Thousand Oaks, CA: Corwin.

15. Hill, C. W. L., \& Jones, G. R. (2012). Strategy management: An integrated approach (10 ${ }^{\text {th }}$ ed.). Boston: South-Western.

16. Hunger, D. J., \& Wheelen, T. L. (2010). Strategic management and business policy (5 ${ }^{\text {th }}$ ed.) Upper SaddlRiver, NJ: Pearson Prentice Hall.

17. Jones, G. R., \& George, J. M. (2007). Essentials of contemporary management (2 ${ }^{\text {nd }}$ ed.). Boston: McGrawHill Irwin.

18. Ketchen, D. J., Eisner, A. B., Dess, G. G., \& Lumpkin, G. T. (2009). Strategy. Boston: McGraw-Hill Irwin.

19. Krizan, A. C., Merrier, P., Logan, J., \& Williams, K. (2008). Business communication ( $7^{\text {th }}$ ed.). Mason, $\mathrm{OH}$ : Thomson South-Western.

20. Lewin, K. (1947). Frontiers in group dynamics: Concept, method and reality in social science; social equilibria and social change. Human Relations, 1(1), 5-41. doi: 10.1177/001872674700100103

21. Luthans, F., \& Doh J. P. (2012). International management: culture, strategy, and behavior (8th ed.). Boston: McGraw-Hill Irwin.

22. London, T., \& Hart, S. L. (2011). Next generation business strategies for the base of the pyramid. Upper Saddle Creek, NJ: Pearson Education, Inc.

23. Lussier, R. N., \& Achua, C. F. (2007). Leadership: Theory, application, skill development. Mason, OH: Thomson South-Western.

24. Mehmood, Z., \& Arif, M. (2011). Leadership and HRM: Evaluating new leadership styles for effective human resource management. International Journal of Business \& Social Science, 2(15), 236-243.

Retrieved from http://www.ijbssnet.com/journals/Vol_2_No_15_August_2011/26.pdf

25. Nadim, A., \& Khan, M. (2013). The moderating role of employee engagement on the relationship of determinants of job satisfaction, and job satisfaction itself. Business \& Management Review, 2(11), 1-12. Retrieved from http://search.ebscohost.com.prx-warner.lirn.net/login.aspx?direct=true\&db=bth\&AN= 87991912\&site=ehost-live

26. Noe, R. A., Hollenbeck, J. R., Gerhart, B., \& Wright, P. M. (2010). Human resource management (2nd ed.). New York: McGraw-Hill Irwin.

27. Pearce, J. A., \& Robinson, R. B. (2007). Strategic management $\left(10^{\text {th }}\right.$ ed.). Boston: McGraw-Hill Irwin.

28. Peng, M. W. (2006). Global strategy. Mason, OH: Thomson South-Western.

29. Porth, S. J. (2003). Strategic management: A cross-functional approach. Upper Saddle Creek, NJ: Prentice Hall. 
30. Rajaeepour, S., Arbabisarjou, A., Zivarirahman, M., \& Shokouhi, S. (2012). Relationship between organizational structure and organizational alienation. Interdisciplinary Journal of Contemporary Research in Business, 3(12), 188-196. Retrieved from http://search.proquest.com/docview/1027147758? accountid $=35797$

31. Robbins, S. P. (2000). Managing today. Upper Saddle Creek, NJ: Prentice Hall.

32. Rodrigues, C. (2001). International management. Cincinnati, OH: South-Western College PublishingThomson Learning.

33. Schein, E. H. (1985). Organizational culture and leadership. San Francisco: John Wiley \& Sons.

34. Segal-Horn, S. (2002). The strategy reader. Malden, MA: Blackwell Publishers, Ltd.

35. Senge, P. M. (1990). The fifth discipline. New York: Currency Doubleday Books.

36. Tallman, S. (2009). Global strategy. Hoboken, NJ: John Wiley \& Sons, Ltd.

37. Theodore, J. (2003). Holistic management. Revista EAN. 47 enero-abril.

38. Theodore, J. (2012). Learning organizations, the American employee and manager, and the developmental role of the social sciences. Global Journal of Management and Business Research, 12(4).

39. Theodore, J. (2013). Absence of transformational leadership in Greek enterprises results in the inability of forming learning organizations. International Business \& Economics Research Journal, 12(6), 701706. Retrieved from http://journals.cluteonline.com/index.php/ IBER/article/view/7874/7933

40. Thompson, A. A., Strickland, A. J., \& Gamble, J. (2009). Boston: Crafting and Executing Strategy. McGraw-Hill Irwin.

41. Ulrich, D., \& Ulrich, W. (2010). The why of work. Boston: McGraw-Hill.

42. Wilden, R., Gudergan, S., \& Lings, I. (2010). Employer branding: Strategic implications for staff recruitment. Journal of Marketing Management, 26(1), 56-73. doi: 10.1080/02672570903577091 